\title{
Antimicrobial Screening of Medicinal Plants Popularly used in Mato Grosso for Treating Infections: Advances on the Evaluation of Conyza bonariensis (L.) Cronquist in vitro and in vivo Antibacterial Activities
}

\author{
Cristiane Coimbra de Paula ${ }^{1}$, Domingos Tabajara De Oliveira Martins ${ }^{1}$, Karuppusamy Arunachalam ${ }^{1}$, \\ Sikiru Olaitan Balogun ${ }^{1,2}$, Quessi Irias Borges ${ }^{1}$, Marcelo Garcia Picone' ${ }^{1}$, Wander Miguel de Barros ${ }^{3}$, \\ Regilane Matos da Silva Prado ${ }^{1,4}$
}

\section{Cristiane Coimbra de Paula ${ }^{1 *}$, Domingos Tabajara De Oliveira Martins ${ }^{1}$, Karup- pusamy Arunachalam', Sikiru Olaitan Balogun ${ }^{1,2}$, Quessi Irias Borges ${ }^{1}$, Marcelo Garcia Picone', Wander Miguel de Barros $^{3}$, Regilane Matos da Silva Prado ${ }^{1,4}$ \\ 'Área de Farmacologia, Departamento de Ciências Básicas de Saúde, Facul- dade de Medicina, Universidade Federal de Mato Grosso (UFMT), Cuiabá, Mato Grosso, BRAZIL. \\ ${ }^{2}$ Faculdade Noroeste do Mato Grosso - AJES, Avenida Gabriel Muller, s/n, Centro, Juína, Mato Grosso, BRAZIL. ${ }^{3}$ Programa de Pós-Graduação em Ciência e Tecnologia de Alimentos, Instituto Federal de Educação, Ciência e Tecnologia de Mato Grosso (IFMT), Cuiabá, Mato Grosso, BRAZIL. ${ }^{4}$ Centro Universitário Católica de Quixadá (UNICATOLICA), Quixadá, Ceará, BRAZIL.}

Correspondence

Prof. Cristiane Coimbra de Paula Universidade Federal de Mato Grosso, Av. Fernando Corrêa da Costa, no 2367, Boa Esperança, Cuiabá, Mato Grosso, 78060-900, BRAZIL.

Phone no: +55 (65) 99237-1941

Email: cristianepaula4@gmail.com

History

- Submission Date: 10-04-2018.

- Review completed: 22-05-2018

- Accepted Date: 18-09-2018.

DOI : 10.5530/pj.2018.6s.28

Article Available online http://www.phcogj.com/v10/i6s

Copyright

(C) 2018 Phcog.Net. This is an open-access article distributed under the terms of the Creative Commons Attribution 4.0 International license.

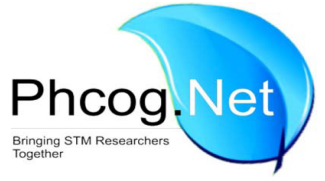

\begin{abstract}
Objective The aim of this study was to screen a group of medicinal plants' extracts used in the treatment of ailments related to infections in the Brazilian popular medicine. And to carry out in vivo toxicity and antibacterial studies on Conyza bonariensis (Asteraceae) leaves and roots methanolic extracts selected based on the screening. Methods: Eleven methanolic extracts obtained from nine plants, reportedly used in the treatments of infections from the state of Mato Grosso, Brazil, were initially screened for their in vitro antibacterial and antifungal activities employing disc diffusion and broth micro dilution assays. Preliminary phytochemical analysis was carried out. The most promising extract based on our results and previous literature reports was then evaluated in the in vivo antibacterial activities using mouse model of bacterial infection induced by Staphylococcus aureus and Escherichia coli. In addition, in vivo acute toxicity was conducted to evaluate the safety profile of the extracts. Results: All of the extracts tested were active against at least one of the bacterial and fungal strain tested with activities ranging from moderate to weak. Phytochemical analyses of MECbl and MECbr demonstrated the presence of free steroids and coumarins in MECbl and flavonoids, tanins, free steroids, reduced anthraquinones and coumarins in $\mathrm{MECBr}$. Oral administration of MECbl and MECbr up to $5000 \mathrm{mg} / \mathrm{kg}$ did not provoked any toxicological events in the mice, thus suggesting that the $L_{50}$ is higher than $5000 \mathrm{mg} / \mathrm{kg}$. In vivo antibacterial assay demonstrated superior prophylactic activity of MECbl compared to MECbr. Conclusion: MECbl and MECbr are safe when administered acute orally at doses up to $5000 \mathrm{mg} / \mathrm{kg}$. Methanolic extracts of Conyza bonariensis possessed in vitro antibacterial and antifungal activities. Considerable in vivo antibacterial activities were observed in bacterial infection model for both MECbl and MECbr, effects comparable to that of meropenem, in some cases. Both extracts present in common free steroids and coumarins. The current in vivo antibacterial activity study further lend supports to the use of Conyza bonariensis in the treatment of infections in many traditional medicines.
\end{abstract}

Key words: Medicinal plants, Conyza bonariensis, Antimicrobial, Mato Grosso, Acute toxicity Preliminary phytochemistry

\section{INTRODUCTION}

Human infections are a serious public health problem because many pathogens such as bacteria and yeast are becoming increasingly resistant to antibiotics. ${ }^{1}$

Despite the great advances achieved by science, among the ten main causes of death worldwide, which include ischaemic heart disease, stroke, diarrhea, HIV/ AIDS, malaria, tuberculosis, pre-term birth complications and birth asphyxia and birth trauma, the lower respiratory infections top the list. ${ }^{2}$ It is estimated that the so called 'super-microorganisms' alone will be responsible for over 10 million deaths by 2050, making it imperative the search for alternative treatments to microorganisms which are unresponsive to most modern antibiotics. ${ }^{3}$ Similarly, opportunistic fungal infections and resistance to antifungal agents have increased significantly in immunocompromised patients and these infections are responsible for a high rate of morbidity/mortality in severe cases. ${ }^{1,4}$

The growing need for more effective and safe antimicrobial agents has led to the renewal of multidisciplinary investigation on natural products, where new approaches combined with traditional techniques, are accelerating tracking of substances, which present antimicrobial activities. In addition, it has also allowed identification of the molecular targets responsible for their effects, moreover, many of these substances present new mechanisms of action. ${ }^{4}$ Medicinal plants constitute an arsenal of chemicals

Cite this article: Paula CC, Martins DTO, Arunachalam K, Balogun SO, Borges QI, Picone MG, Barros WM, Prado RMS. Antimicrobial Screening of Medicinal Plants Popularly used in Mato Grosso for Treating Infections: Advances on the Evaluation of Conyza bonariensis (L.) Cronquist in vitro and in vivo Antibacterial Activities. Pharmacogn J. 2018;10(6)Suppl:s152-s166. 
that could be exploited by human to prevent microbial invasion and have been a major source for drug development. All over the world, plant extracts and their products are used in the treatment of bacterial, fungal and viral infections. ${ }^{5}$ The use of plants and preparations made from them to treat infections is an ancient practice used by a large portion of the world's population, particularly in developing countries where there is a reliance on traditional medicine for a variety of diseases. ${ }^{6-7}$ Many plants are used in Brazil in the form of crude extracts, infusion or poultice to treat common infections, without any scientific evidence. Due to the mega biodiversity of the Brazilian medicinal plants, many studies have been conducted in an attempt to validate the antimicrobial properties of popular use in a given region, of these preparations..$^{8-9}$

Brazil possesses the largest floristic diversity on Earth, containing six continental biomes, the Amazon rainforest, the Cerrado the Caatinga, the Atlantic forest, the Pantanal and the Pampas, with Amazon rainforest the most noteworthy, since it is the largest tropical forest in the world. In addition, the diversity of plant species constitutes an endless source for the research on herbal remedies for the development of new molecules with biological activities. ${ }^{2}$ The state of Mato Grosso (MT), the largest farming and livestock producer in Brazil, contains three important bio geographical regions (Amazon rain forest, Brazilian Savannah and Pantanal) and a rich ethnic-cultural diversity, represented by 42 indigenous groups and traditional Quilombola, Cabocla and Riverine Communities. In vitro antimicrobial tests allow selection of crude extracts of plants with potential properties through use of chemical and pharmacological studies. In fact, majority of studies on antimicrobial potentials of medicinal plants are restricted to in vitro studies. ${ }^{10-12}$ However, in vitro susceptibility testing is only one-step in the evaluation of the potential efficacy of antimicrobial agents against microbial organisms. Based on the aforementioned, this study aimed at screening selected medicinal plants from Mato Grosso, through in vitro antimicrobial activity methods with the view of selecting the most promising for in vivo antibacterial study.

As part of our on-going research towards development of new antimicrobial for use in humans, the aim of the present study was to screen medicinal plants used popularly in the state of Mato Grosso for treating infections, with the sole purpose of selecting the most promising plant. Conyza bonariensis extracts were selected for further studies based on its in vitro antimicrobial activities and the availability of extensive reports of its use in ethnomedicine. The important uses include among others microbial infections; wound healing, constipation, diarrhea, and inflammation, just to mention but few. Numerous species of the genus Conyza have been extensively used in popular folk medicine. The plant has traditionally been used to treat rheumatism, gout, cystitis, nephritis, dysmenorrhoea, dental pain, and headache. ${ }^{8,13-20}$

There are also reports of several biological, phytochemical and pharmacological studies of different extracts or derivatives from this plant that have supported its popular use in many cases. Despite several in vitro studies, none has ventured to evaluate Conyza bonariensis in vivo antibacterial activity in experimental rodents. Thus in the present work, we present its in vitro activities using different methods, the acute toxicity and it's in vivo prophylactic effect in systemic infection model.

\section{MATERIALS AND METHOD}

\section{Experimental Animals}

Albino mice Mus musculus, Swiss-Webster strain (25-30 g) were used for the in vivo anti-bacterial studies. Animals were maintained in polypropylene cages at $26^{\circ} \mathrm{C}$ in a $12 \mathrm{~h}$ light-dark cycle, with free access to standard laboratory chow and water. Groups of six animals were used for each experiment. The experimental protocol followed the International Principles for the Biomedical Research Involving Animal ${ }^{13}$ and was approved by the Committee on the Use of Animal for experimentation (CEUA/UFMT) with protocol number 23108,047577/09-1. The number of animals and the intensity of the stimuli used were minimum required to demonstrate in a consistent manner the effect of treatments.

\section{Microorganisms}

All bacterial and fungal strains used in in vitro experimental models were from American Type Culture Collection (ATCC) strains commercially acquired from Newprov (Paraná, Brazil). These were Enterococcus faecalis (ATCC-29212), Enterobacer aerogene (ATCC-13048), Escherichia coli (ATCC-25922), Klebsiella pneumonia (ATCC-13883), Pseudomonas aeruginosa (ATCC-27853), Proteus mirabilis (ATCC-25933), Shigella flexneri (ATCC-12022), Staphylococcus aureus (ATCC-25923), Strepto-

Table 1: Plants collected, place of collection in Mato Grosso State, Brazil, and voucher number.

\begin{tabular}{|c|c|c|c|c|c|}
\hline $\begin{array}{l}\text { Scientific name/ } \\
\text { Family }\end{array}$ & $\begin{array}{l}\text { Main vernacular } \\
\text { name }\end{array}$ & Part collected/Medicinal use & Place of collection & Voucher number & Reference \\
\hline $\begin{array}{l}\text { Cariniana rubra } \\
\text { Gardner ex Miers/ } \\
\text { Lecitidaceae }\end{array}$ & Jequitibá-vermelho & $\begin{array}{l}\text { Leaves/depurative, ulcer, throat } \\
\text { inflammation }\end{array}$ & $\begin{array}{l}\text { Cuiabá, latitude: } 15^{\circ} \\
35^{\prime} 46^{\prime \prime} \text { and longitude } \\
56^{\circ} 05^{\prime} 48^{\prime \prime}\end{array}$ & 18,337 & [5] \\
\hline $\begin{array}{l}\text { Lafoensia pacari A. } \\
\text { St.-Hil./Lythraceae }\end{array}$ & Mangava-brava & $\begin{array}{l}\text { Stem bark/ infections, diarrhea } \\
\text { with blood, venereal disease, } \\
\text { chilblain, furuncle, female } \\
\text { infection (with discharge), } \\
\text { tuberculosis; inflammation, } \\
\text { uterine inflammation, uterus and } \\
\text { ovary infection, kidney infections, } \\
\text { wound healing }\end{array}$ & $\begin{array}{l}\text { Várzea Grande, } \\
\text { latitude: } 15^{\circ} 51^{\prime} 58^{\prime \prime} \mathrm{S} \\
\text { and longitude } 52^{\circ} 15^{\prime} \\
37^{\prime \prime} \mathrm{W}\end{array}$ & 35,577 & [5] \\
\hline $\begin{array}{l}\text { Stryphnodendron } \\
\text { rotundifolium Mart./ } \\
\text { Fabaceae }\end{array}$ & Barbatimão & $\begin{array}{l}\text { Stem bark/ antimicrobial, anti- } \\
\text { ulcer and anti-inflammatory } \\
\text { properties }\end{array}$ & $\begin{array}{l}\text { Santo Antonio do } \\
\text { Leverger, latitude: } 15^{\circ} \\
51^{\prime} 56^{\prime \prime} \mathrm{S} \text { and longitude: } \\
56^{\circ} 04^{\prime} 36^{\prime \prime} \mathrm{W}\end{array}$ & 35,584 & [5] \\
\hline $\begin{array}{l}\text { Anacardium } \\
\text { humile A. St. -Hil./ } \\
\text { Anacardiaceae }\end{array}$ & Cajuzinho-do-campo & $\begin{array}{l}\text { Leaves and stem bark/diarrhea, } \\
\text { (superficial skin mycoses), general } \\
\text { Infection, gastritis, wound healing, } \\
\text { throat infection }\end{array}$ & $\begin{array}{l}\text { Cuiabá, latitude: } 15^{\circ} \\
32^{\prime} 50^{\prime \prime} \mathrm{S} \text { and longitude } \\
56^{\circ} 09^{\prime} 26^{\prime \prime} \mathrm{W}\end{array}$ & 31,789 & [5] \\
\hline
\end{tabular}




\begin{tabular}{|c|c|c|c|c|c|}
\hline $\begin{array}{l}\text { Scientific name/ } \\
\text { Family }\end{array}$ & $\begin{array}{l}\text { Main vernacular } \\
\text { name }\end{array}$ & Part collected/Medicinal use & Place of collection & Voucher number & Reference \\
\hline $\begin{array}{l}\text { Handroanthus } \\
\text { heptaphyllus (Vell.) } \\
\text { Mattos/Bignoniacee }\end{array}$ & Ipê-roxo & $\begin{array}{l}\text { Stem bark/ DE: wound healing; } \\
\text { malaria, stomach infection in } \\
\text { the ovary, osteoporosis, uterine } \\
\text { problems antibiotic, rheumatism } \\
\text {, Bladder infection, urinary } \\
\text { infection }\end{array}$ & $\begin{array}{l}\text { Cuiabá, latitude: } 15^{\circ} \\
35^{\prime} 46^{\prime \prime} \text { S and longitude } \\
56^{\circ} 05^{\prime} 48^{\prime \prime} \mathrm{W}\end{array}$ & 39,140 & [5] \\
\hline $\begin{array}{l}\text { Gossypium barbadense } \\
\text { L./Malvaceae }\end{array}$ & Algodão & $\begin{array}{l}\text { Leaves/ infections, female } \\
\text { infection (with discharge) flu, } \\
\text { inflammation, ovarian infection, } \\
\text { uterine infection, vaginal } \\
\text { infection with discharge, uterine } \\
\text { inflammation, uterine and ovarian } \\
\text { inflammation, wound healing, } \\
\text { injury }\end{array}$ & $\begin{array}{l}\text { Poconé, Latitude: } 16^{\circ} \\
02^{\prime} 90^{\prime} \text { S and longitude } \\
05643^{\prime} 49^{\prime} \text { 'W. }\end{array}$ & 31,755 & [5] \\
\hline $\begin{array}{l}\text { Plantago major L./ } \\
\text { Plantaginaceae }\end{array}$ & Tanchagem & $\begin{array}{l}\text { Leaves/ skin diseases, infectious } \\
\text { diseases, digestive organs, } \\
\text { respiratory organs, reproduction, } \\
\text { tumours, pain, fever }\end{array}$ & $\begin{array}{l}\text { Santo Antônio do } \\
\text { Leverger, latitude: } 15^{\circ} \\
51^{\prime} 56^{\prime \prime} \text { S and longitude: } \\
56^{\circ} 04^{\prime} 36^{\prime \prime} \mathrm{W}\end{array}$ & 31,790 & [14] \\
\hline $\begin{array}{l}\text { Cecropia } \\
\text { pachystachyaTrécul/ } \\
\text { Cecropiaceae }\end{array}$ & Embaúba & $\begin{array}{l}\text { Leaves/ anti-inflammatory, } \\
\text { antitussive, expectorant, anti- } \\
\text { asthmatic and hypoglycaemic } \\
\text { effects }\end{array}$ & $\begin{array}{l}\text { Cuiabá, latitude: } \\
14^{\circ} 47^{\prime} 23.200^{\prime \prime} \text { S } \\
\text { and longitude: } \\
56^{\circ} 19^{\prime} 10.008^{\prime \prime} \mathrm{W}\end{array}$ & 34,119 & [5] \\
\hline $\begin{array}{l}\text { Conyza bonariensis } \\
\text { (L.) Cronquist/ }\end{array}$ & $\begin{array}{l}\text { Margaridinha-do- } \\
\text { campo }\end{array}$ & $\begin{array}{l}\text { Leaves and roots/ laxative, } \\
\text { diarrhoea, cough, aphrodisiac, } \\
\text { gastrointestinal problems } \\
\text { including diarrhoea }\end{array}$ & $\begin{array}{l}\text { Campo Verde, latitude: } \\
15^{\circ} 32^{\prime} 48^{\prime \prime} \mathrm{S} \text { and } \\
\text { longitude: } 55^{\circ} 10^{\prime} \\
08^{\prime \prime} \mathrm{W}\end{array}$ & 21,438 & [15] \\
\hline
\end{tabular}

coccus pyogenes (ATCC-19615), Candida albicans - fluconazole-resistant (ATCC $^{*} 10231^{\mathrm{TM}}$ ), Candida albicans (ATCC-64550), Candida grablata (ATCC-90030), Candida kruzei (ATCC-6258) and Candida parapsilosis (ATCC-40058). For the experiments, all bacteria were cultured at $37^{\circ} \mathrm{C}$ in agar Muller- Hinton and yeasts on Sabouraud agar, $24 \mathrm{~h}$ prior to testing to become viable and reproducible experiment

\section{Botanical materials}

Different parts of the plants used in the screening assays were collected during the period of 2008 - 2010 from various locals situated in the different municipalities indicated in the Table 1 . All plants were identified by the taxonomist Dr. Rosilene Rodrigues Silva and were deposited in the Herbarium of Universidad Federal de Mato Grosso (UFMT). The accepted plants names were checked with www.theplantlist.org, on May 21, 2015, while the geographical origin status was based on Rio de Janeiro Botanical Garden database of list of species of the Brazilian flora (available at http: http://floradobrasil.jbrj.gov.br/).

The antimicrobial activities of nine plants (11 extracts) with popular uses related to bacterial or fungal infections were evaluated. These were Anacardium humile A. St. -Hil. (leaves and stem bark), Cecropia pachystachya Trécul (leaves), Gossypium barbadense L. (leaves), Plantago major L. (leaves), Cariniana rubra Gardner ex Miers (leaves), Lafoensia pacari A.St.-Hil. (Stem bark), Stryphnodendron rotundifolium Mart. (stem bark), Handroanthus heptaphyllus (Vell.) Mattos (stem bark), Conyza bonariensis (L.) Cronquist (leaves and root) on Gram-positive and Gram-negative bacteria and fungal strains.

\section{Extract preparations}

The extracts of the plants were prepared at the Natural Products Laboratory of Pharmacology, Faculty of Medicine, UFMT. The parts of the plants were collected cleaned and dried in the shade at room temperature for a period of 7 days, were milled and sieved using electric miller, result- ing in $100 \mathrm{~g}$ of powdered plant material. After which they were obtained by soaking each part of powder in cold absolute methanol solvent (1:10 $\mathrm{w} / \mathrm{v}$ ) for 7 days at $25^{\circ} \mathrm{C}$

The extracts were filtered and concentrated in vacuum at $600 \mathrm{~mm} \mathrm{Hg}$ rotary evaporator and the residual solvent was removed in an oven at $40^{\circ} \mathrm{C}$. At the time of use, extracts were dissolved in Tween 80 (Synth). The extracts were Anacardium humile leaves and stem bark (MEAhl and MEAhs), Cecropia pachystachya (MECp), Gossypium barbadense (MEGb), Plantago major (MEPm), Cariniana rubra (MECr), Lafoensia pacari (MELp), Stryphnodendron rotundifolium (MESr), Handroanthus heptaphyllus (MEHh), Conyza bonariensis leaves and root (MECbl and MECbr, respectively).

\section{Preliminary phytochemical analysis}

Preliminary phytochemical tests were performed to identify the following principal secondary metabolite groups: tannins, flavonoids, steroids and triterpenoids, saponins, alkaloids, coumarins and quinones, through a process of qualitative prospecting. ${ }^{16}$ The preliminary phytochemical analysis was carried out by using the following standard methods. Test for tannins: $10 \mathrm{~mL}$ of bromine water was added to the $0.5 \mathrm{~g}$ crude extracts. Decoloration of bromine water showed the presence of tannins. Tests for flavonoids shinoda test: Pieces of magnesium ribbon and $\mathrm{HCl}$ concentrated were mixed with crude plant extracts after few minutes and pink color showed the presence of flavonoid.

Test for steroids: steroids was sought by the reaction of Liebermann, 10 $\mathrm{mL}$ of crude extracts were evaporated. The residue was dissolved in 0.5 $\mathrm{mL}$ of hot acetic anhydride; we added $0.5 \mathrm{~mL}$ of the filtrate chloroforme. Treated with the reagent of Libermann Burchardt. The appearance, at the interphase, a ring of blue-green, showed a positive reaction.

Test for triterpenoids: Liebermann - Burchard's test $2 \mathrm{mg}$ of dry extracts were dissolved in acetic anhydride, heated to boiling, cooled and then 1 
$\mathrm{mL}$ of concentrated sulphuric acid was added along the sides of the test tube. Formation of a pink colour indicates the presence of triterpenoids. Test for saponins: $5.0 \mathrm{~mL}$ of distilled water was mixed with crude plant extracts in a test tube and it was mixed vigorously. The frothing was mixed with few drops of olive oil and mixed vigorously and the foam appearance showed the presence of saponins.

Test for anthraquinones: $10 \mathrm{~mL}$ of benzene was added in $6 \mathrm{~g}$ of the crude plant extracts in a conical flask and soaked for $10 \mathrm{~min}$ and then filtered. Further $10 \mathrm{~mL}$ of $10 \%$ ammonia solution was added to the filtrate and shaken vigorously for $30 \mathrm{~s}$ and pink, violet, or red color indicated the presence of anthraquinones in the ammonia phase.

Test for alkaloids: Dragendorff's test To $2 \mathrm{mg}$ of the crude extracts $5 \mathrm{~mL}$ of distilled water was added, $2 \mathrm{M} \mathrm{HCl}$ was added until an acid reaction occurs. To this $1 \mathrm{~mL}$ of Dragendorff's reagent was added. Formation of orange or orange red precipitate indicates the presence of alkaloids.

Test for coumarins: Evaporate $5 \mathrm{~mL}$ of ethanolic solution, dissolve the residue in 1-2 $\mathrm{mL}$ of hot distilled water and divide the volume into two parts. Take half the volume as a witness and to add another volume of 0.5 $\mathrm{mL} 10 \% \mathrm{NH}_{4} \mathrm{OH}$. Put two spots on filter paper and examined under UV light. Intense fluorescence indicates the presence of coumarins.

\section{Antimicrobial assays}

\section{Disc diffusion assay}

The disc diffusion method was used for the tests disc. Sterile Filter papers (7 $\mathrm{mm}$ in diameter, (Sensibiodisc-Cecon, São Paulo, Brazil) impregnated with extract solution $(20 \mu \mathrm{L})$ were placed on Muller-Hinton agar (Oxoid, Thermo Fisher Scientific, São Paulo, Brazil) and Saubouraud agar (Oxoid, Thermo Fisher Scientific, São Paulo, Brazil), according to the method of Kirby et al. ${ }^{17}$ against nine bacteria species, being 6 Gramnegative and 3 Gram-positive, and 5 leveduriforms (Candida spp.). The test plates were prepared with Müller-Hintonand Saubouraud agar and were inoculated on the surface with bacterial and fungal suspension respectively, prepared in sterile saline $(0.9 \%)$.

The concentration of the bacterial suspension was adjusted to $0.5 \mathrm{Mac}$ Farland scale $\left(1 \times 10^{5} \mathrm{CFU} / \mathrm{mL}\right)$ and the fungal suspension was adjusted to 1 MacFarland scale $\left(1 \times 10^{5} \mathrm{UFC} / \mathrm{mL}\right)$. The extracts were tested at different concentrations (20 - $0.009 \mu \mathrm{g} / \mathrm{disc})$, using chloramphenicol $(30 \mu \mathrm{g} / \mathrm{disc}$, Sensibiodisc-Cecon, São Paulo, Brazil) and amphotericin B (100 $\mu \mathrm{g} / \mathrm{disc}$, Sensibiodisc-Cecon, São Paulo, Brazil) as the standard drugs. The negative controls for the extracts were as follows: distilled water for MEAhl, MEAHc, MECr, MEHh, DMSO (0.04\%) and Tween 80 (2\%) in distilled water for MEPm, MEGb, MECp, MECbl, MECbr and MELp. The plates were placed in a refrigerator for $4 \mathrm{~h}$, so that the test drug will diffuse throughout the medium. After this period, the plates were incubated at $37^{\circ} \mathrm{C}$ for $24 \mathrm{~h}$ and we subsequently proceeded to measure the zones of inhibition of bacterial growth, considering the active zones of inhibition of bacterial growth $\geq 10 \mathrm{~mm} .{ }^{6}$ Tests were performed in duplicates.

\section{Broth micro dilution}

The antibacterial activities of the extracts were evaluated by determining the minimal inhibitory concentration (MIC) according to guidelines established by Clinical and Laboratory Standards Institute (CLSI). MICs were determined using micro plates of 96 wells according to CLSI guidelines. ${ }^{18}$ Stock solutions of the extracts in distilled water were diluted to give serial twofold dilutions that were added to each medium, resulting in concentrations ranging from $1000-1.9 \mu \mathrm{g} / \mathrm{mL}$ of the extracts. Inoculum of $100 \mu \mathrm{L}$ (final concentration $10^{4} \mathrm{CFU} / \mathrm{mL}$ ) were added to MuellerHinton broth. Chloramphenicol (50 - $3.1 \mu \mathrm{g} / \mathrm{mL}$ ) (Sigma, São Paulo, Brazil) was used as positive control. The culture medium $0.04 \%$ DMSO served as the negative control. Plates were incubated for $24 \mathrm{~h}$ at $35^{\circ} \mathrm{C}$.
The same procedure was used to evaluate the antifungal activity, using the Saubouraud medium (Acumedia, São Paulo, Brazil) incubated for 24 h. Amphotericin B (100 - $3.25 \mu \mathrm{g} / \mathrm{mL})$ (Sigma, São Paulo, Brazil) was used as standard drug. The reading of MIC was performed manually or visually, considering the presence of turbidity in each microplate. ${ }^{19}$

The reading was performed using the microplate reader method. The criteria used to classify the activity of the extracts were: MIC $\leq 100 \mu \mathrm{g} /$ $\mathrm{mL}$ good antimicrobial activity; when the MIC between $100-500 \mu \mathrm{g} /$ $\mathrm{mL}$, moderate activity; MIC above $500-1000 \mu \mathrm{g} / \mathrm{mL}$, weak activity and MIC $\geq 1000 \mu \mathrm{g} / \mathrm{mL}$ inactive. ${ }^{20}$ The MIC is the lowest concentration of the test drug that was able to inhibit completely the bacterial growth in the medium. All tests were conducted in duplicates.

\section{Acute toxicity screening test}

The effect of MECbl and MECbr on the general behavior of conscious animals was evaluated in mice, as previously described by Malone and Robichaud. ${ }^{21}$ Briefly, male and female mice ( $n=3 /$ group) received by gavage (p.o.) MECbl and MECbr at doses of 500, 1,000, 2,000 and 5,000 $\mathrm{mg} / \mathrm{kg}$ body weight (b.w.). One control animal per group, received the vehicle (distilled water, $10 \mathrm{~mL} / \mathrm{kg}$ ). Animals were observed individually in open field at 5, 10, 15, 30, 60, 120 and 240 min and once a day, for a period of 14 days, noting any clinical signs or mortality.

\section{Systemic bacterial infection in mice}

For the systemic infection experiments, ${ }^{22}$ the $\mathrm{MECbl}$ and MECbr were used against two bacterial clinical isolates of $S$. aureus and E. coli. Swiss albino male and female mice, weighing between 25-35 g were allocated into 10 groups of 10 animals each. The negative control group received distilled water (vehicle) orally and the positive control group received meropenem (Biochimico, São Paulo, Brazil) $20 \mathrm{mg} / \mathrm{kg}$ subcutaneously as treatment. In the test groups, different doses $(0.01 ; 0.1 ; 1 ; 10 ; 50 ; 100 ; 200$; 300 and $500 \mathrm{mg} / \mathrm{kg}$ ) of the tested extracts were given orally. The bacterial strains were plated on nutrient agar, $24 \mathrm{~h}$ before the experiment (Biobrás, São Paulo, Brazil).

The bacterial inoculum of $S$. aureus was adjusted to MacFarland 6 scale $\left(21 \times 10^{8} \mathrm{CFU} / \mathrm{mL}\right)$, for $E$. coli the scale was MacFarland 3 scale $\left(9 \times 10^{8}\right.$ $\mathrm{CFU} / \mathrm{mL}$ ). These bacterial concentrations are capable of inducing systemic infection in the animals and causing death in $100 \%$ of the animals in less than 14 days. Bacterial infection was induced by the intraperitoneal administration $(0.2 \mathrm{~mL})$ of the bacterial suspension in BHI broth (Biobrás ${ }^{\circledast}$, São Paulo, Brazil). Treatments of the animals were done immediately and $4 \mathrm{~h}$ after inoculation of the animals, and they were observed for 14 days to record mortality.

\section{Data analysis}

The Bartlett's test was used to test for homogeneity of variance between groups. When no significant heterogeneity was detected, one-way analysis of variance (ANOVA) was applied, followed by Student-NewmanKeuls multiple comparison test. $P<0.05$ level was considered as significant. Graph Pad Prism (c) version 5.01 for Windows (Graph Pad Software, USA) was used for statistical analysis.

\section{RESULTS}

\section{Preliminary phytochemical analysis}

Preliminary phytochemical analysis of the extracts revealed the presence of flavonoids, tanins, alkaloids, free steroids, saponins, reduced anthraquinones, triterpenes and coumarins (Table 2).

MEAhl and MEAhs: methanolic extract of Anacardium humile leaves and stem bark, respectively, MECp: methanolic extract of Cecropia 
Table 2: Preliminary phytochemical analysis of selected medicinal plant methanolic extracts from the state of Mato Grosso, Brazil.

\begin{tabular}{|c|c|c|c|c|c|c|c|c|c|}
\hline Extracts & Flavonoids & Tanins & Alkaloids & Free steroids & Saponins & $\begin{array}{c}\text { Reduced } \\
\text { anthraquinones }\end{array}$ & anthraquioiones & Triterpenoids & Coumarins \\
\hline MEAhl & + & + & - & + & + & + & - & - & + \\
\hline MEAhs & - & + & - & + & - & + & - & - & + \\
\hline $\operatorname{MEC} p$ & + & + & - & + & - & + & - & - & + \\
\hline$M E G b$ & - & + & - & + & - & + & - & - & + \\
\hline $\mathrm{MEPm}$ & + & - & - & + & - & + & - & - & + \\
\hline $\mathrm{MECr}$ & + & + & - & - & + & + & - & + & + \\
\hline $\operatorname{ME} L p$ & + & + & + & - & + & + & - & - & + \\
\hline $\mathrm{MESr}$ & + & + & - & + & + & + & - & - & + \\
\hline $\mathrm{MEHh}$ & + & - & - & - & - & + & - & - & + \\
\hline MECbl & $-\mathrm{z}$ & - & - & + & - & - & - & - & + \\
\hline MECbr & + & + & - & + & - & + & - & - & + \\
\hline
\end{tabular}

+ Present in the methanolic extract ; -Absent in the methanolic extract

pachystachya, MEGb: methanolic extract of Gossypium barbadense; MEPm: methanolic extract of Plantago major, MECr: methanolic extract of Cariniana rubra, MELp: methanolic extract of Lafoensia pacari: MESr: methanolic extract of Stryphnodendron rotundifolium, MEHh: methanolic extract of Handroanthus heptaphyllus; MECbl and MECbr: methanolic extract of Conyza bonariensis leaves and roots, respectively.

\section{Antimicrobial activity}

Disc diffusion assay

Antibacterial activities of the plants' methanolic extracts obtained against the Gram-positive and Gram-negative bacteria organisms in the disc diffusion method are shown in Table 3. All the plant extracts tested demonstrated antibacterial activity against one or more bacterial agents. However, they differ in their spectrum of activities against the microorganisms. On one hand, none of the extracts was active against $K$. pneumoneae, S. flexneri and P. mirabilis, whereas, E. feacalis was the most sensitive bacterial strain. Chloramphenicol, the standard antibiotic used in this assay was active against all the tested strains (Table 3).

MEAhl and MEAhs: methanolic extract of Anacardium humile leaves and stem bark, respectively, MECp: methanolic extract of Cecropia pachystachya, MEGb: methanolic extract of Gossypium barbadense, MEPm: methanolic extract of Plantago major, MECr: methanolic extract of Cariniana rubra, MELp: methanolic extract of Lafoensia pacari, MESr: methanolic extract of Stryphnodendron rotundifolium, MEHh: methanolic extract of Handroanthus heptaphyllus; MECbl and MECbr: methanolic extract of Conyza bonariensis leaves and root, respectively.

\section{Broth microdilution assay}

All the plant extracts showed moderate to weak activities against the Gram-positive and Gram-negative bacteria tested in this assay, with MICs ranging from $250-1000 \mu \mathrm{g} / \mathrm{mL}$ as shown in Table 4 . Whereas chloramphenicol, the standard drug, demonstrated good activity against all tested bacteria with MIC ranging between 0.5 and $2.0 \mu \mathrm{g} / \mathrm{mL}$.

MIC = Minimum inhibitory concentration. Good activity: MIC $\leq 100$ $\mu \mathrm{g} / \mathrm{mL}$; Moderate activity: $100<\mathrm{MIC}<500 \mu \mathrm{g} / \mathrm{mL}$; Weak activity: $500<$ $\mathrm{MIC}<1000 \mu \mathrm{g} / \mathrm{mL}$; Inactive: $\geq 1000 \mu \mathrm{g} / \mathrm{mL} .^{20}$

Ef = Enterococcus faecalis; $\mathrm{Sa}=$ Staphylococcus aureus; $S p=$ Streptococcus pyogenes; Ec = Escherichia coli; Kp = Klebsiella pneumoniae; $\mathrm{Pa}=\mathrm{Pseu}$ domonas aeruginosa; $S f=$ Shigella flexneri; $\mathrm{Pm}=$ Proteus mirabilis; $\mathrm{Ea}=$ Enterobacter aerogenes.
MEAhl and MEAhs: methanolic extract of Anacardium humile leaves and stem bark, respectively, MECp: methanolic extract of Cecropia pachystachya, MEGb: methanolic extract of Gossypium barbadense; MEPm: methanolic extract of Plantago major, MECr: methanolic extract of Cariniana rubra, MELp: methanolic extract of Lafoensia pacari: MESr: methanolic extract of Stryphnodendron rotundifolium, MEHh: methanolic extract of Handroanthus heptaphyllus; MECbl and MECbr: methanolic extract of Conyza bonariensis leaves and root, respectively.

\section{Antifungal activity}

\section{Disc diffusion assay}

The antifungal activities of the extracts using disc diffusion method can be seen in Table 5 . Only 5 of the extracts demonstrated activity against the yeast strains employed, with C. bonariensis displaying higher spectrum of antifungal activity.

MEAhl and MEAhs: methanolic extract of Anacardium humile leaves and stem bark, respectively, MECp: methanolic extract of Cecropia pachystachya, MEGb: methanolic extract of Gossypium barbadense; MEPm: methanolic extract of Plantago major, MECr: methanolic extract of Cariniana rubra, MELp: methanolic extract of Lafoensia pacari: MESr: methanolic extract of Stryphnodendron rotundifolium, MEHh: methanolic extract of Handroanthus heptaphyllus; MECbl and MECbr: methanolic extract of Conyza bonariensis leaves and root, respectively.

\section{Broth microdilution assay}

Similar to the results obtained in the antibacterial micro broth dilution assay, all plants' extracts demonstrated moderate to weak activity against all the fungal strains tested. However, Amphotericin B showed superior activity against all the leveduriform strains with MIC ranging between 0.25 and $1.0 \mu \mathrm{g} / \mathrm{mL}$ (Table 6).

MEAhs and MEAhl: methanolic extract of Anacardium humile stem and leaves, respectively, MECr: methanolic extract of Cariniana rubra, MECp: methanolic extract of Cecropia pachystachya, MECbl and MECbr: methanolic extract of Conyza bonariensis leaves and root, respectively.MEGb: methanolic extract of Gossypium barbadense; MELp: methanolic extract of Lafoensia pacari: MEPm: methanolic extract of Plantago major, MESo: methanolic extract of Stryphnodendron rotundifolim, MEHh: methanolic extract of Handroanthus heptaphyllus.

In the selection of the plants extracts that were included in the in vivo toxicological and in vivo antibacterial studies, we employed various 


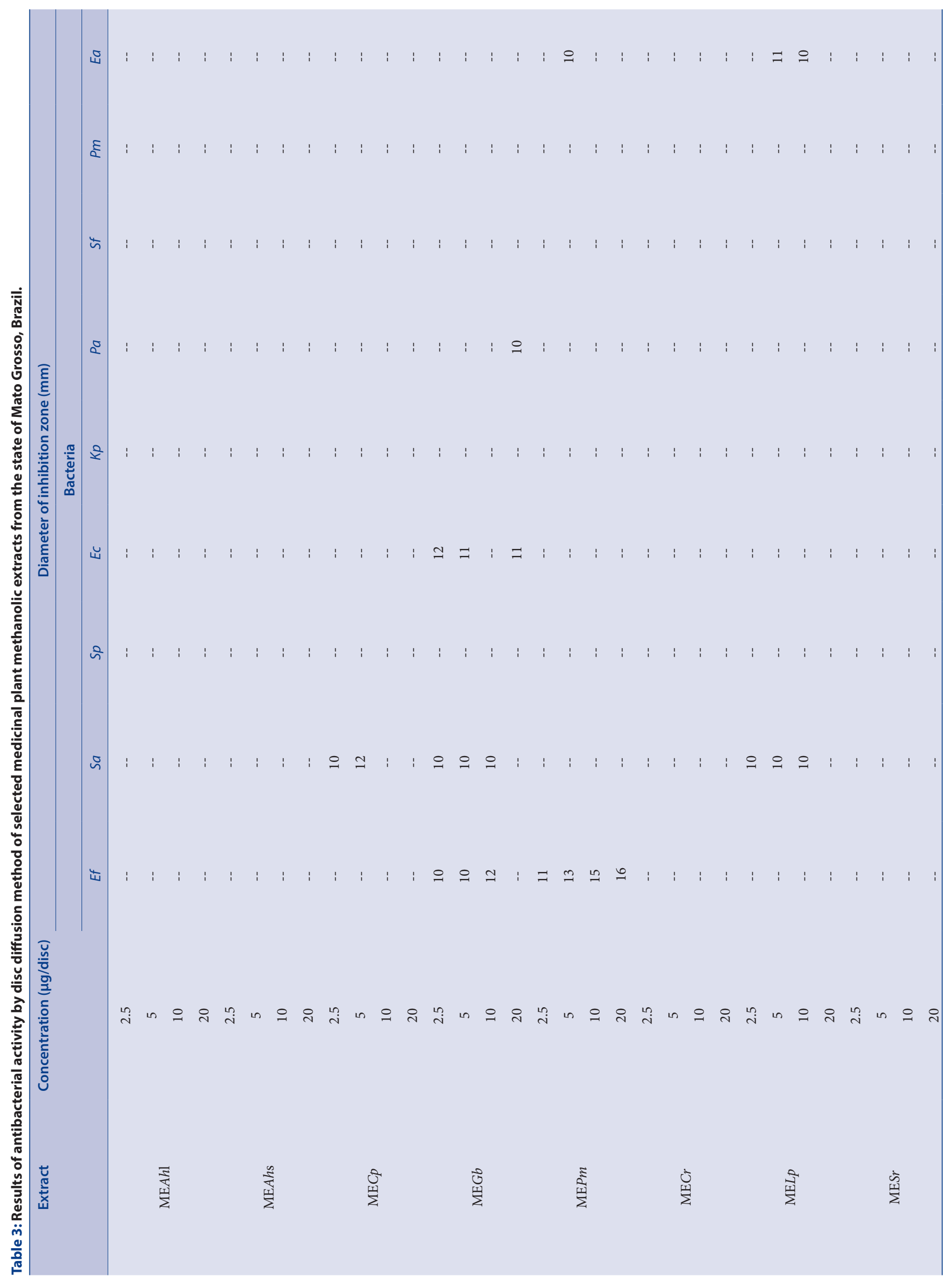




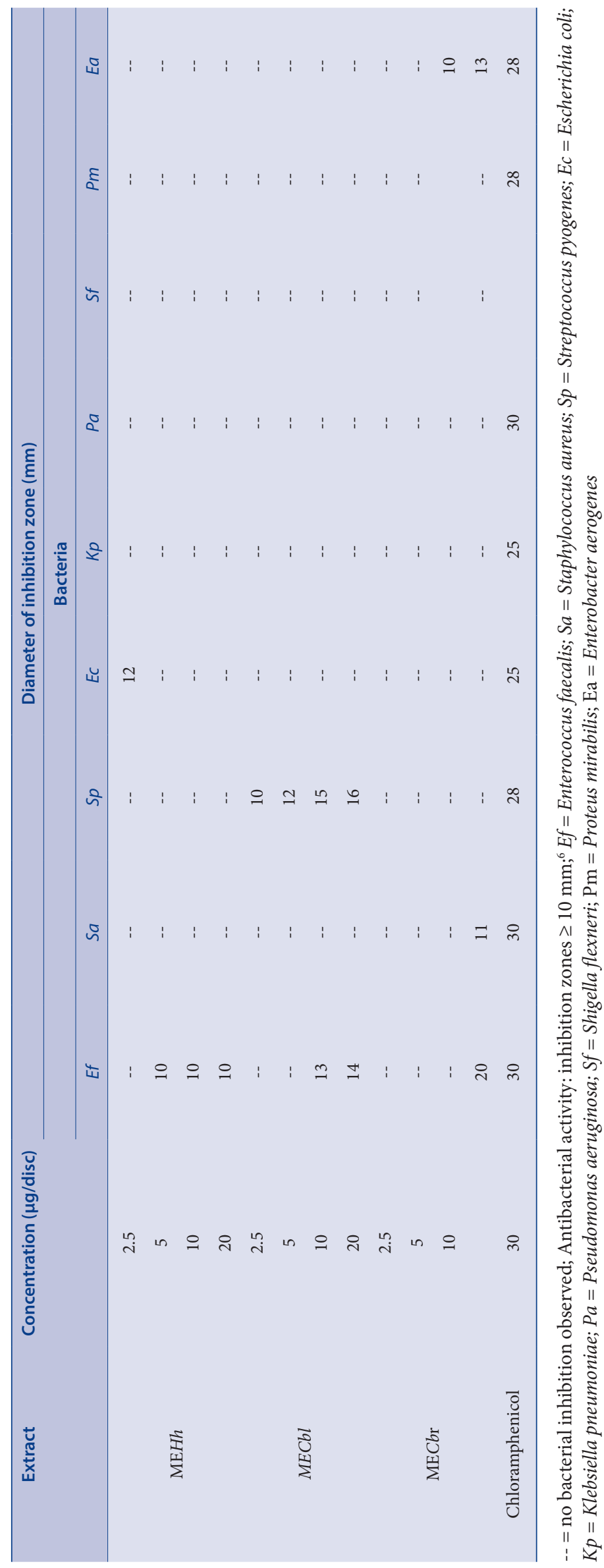

criteria. These criteria specifically were: the preponderance of reports that have demonstrated scientific evidence of the ethnomedicinal uses of the plant in question; the potential antibacterial and antifungal activities observed; literature evidence concerning its pharmacological and biological activities, reports of toxicity, if any, and if there is study with human subject. We therefore proceeded only with the methanolic extracts of Conyza bonariensis leaves and root for the in vivo toxicological and antimicrobial evaluations.

\section{In vivo acute toxicity study}

The in vivo oral acute toxicity study of the two extracts MECb extracts (root and leaves) demonstrated that both extracts are safe at doses up to $5000 \mathrm{mg} / \mathrm{kg}$, as no behavioural or deaths were recorded after 14 days of observations (Table 7).

\section{Systemic bacterial infection in mice}

Table 8, shows the protective effects of MECbl, MECbr and meropenem, on a murine systemic infection model induced by a variety of pathogens. The protective effect of MECbl was comparable to that of imipenem and stronger than that of MECbr for infections induced by S. aureus. For the other gram-negative bacterial infection i.e. E. coli, its protective effect was inferior to that meropenem, but superior to MECbr, which lack effect on the E. coli. In of general, by observing the in vitro and in vivo results, it is evident that $S$. aureus was more susceptible to the extracts than the E. coli. Intriguingly, at the maximum dose of $500 \mathrm{mg} / \mathrm{kg}$ there seems to be reductions in the prophylactic activities of the two extracts.

\section{DISCUSSION}

As part of our research goals, in identifying medicinal plants with potential for phytotherapeutic ends, we screened selected medicinal plants from the Cerrado of the state of Mato Grosso for potential antimicrobial use. Generally, the antimicrobial activities of natural products are screened using in vitro biological assays susceptibility testing. ${ }^{37}$ Several plants were selected based on initial ethnobotanical survey using for screening of their antibacterial activity the disc diffusion, agar diffusion and micro dilution methods, that are the most commonly used for screening plant extracts with potential antimicrobial activities. ${ }^{38}$

Initial screening of the 11 extracts showed that all the extracts displayed antibacterial and antifungal activities to more than one pathogen tested, although at varying degrees. Some of these plants have been previously studied, with different solvents, parts and sometimes using different strains and different methodological approachs. ${ }^{23-36}$ Although, there are some reports concerning antimicrobial activities of some of the plants tested (Table 9), the main difficulties in comparing previous studies, lies in the fact that the criteria, method and end-points used for reporting the activity are very diverse. As can be seen in the table in the case of Gossypium barbadense, the minimum concentration used in the study by Ikobi et $_{\text {al. }}{ }^{32}$ and regarded to represent antibacterial activity, is considered in our study to be too high (10 folds increase compared to the maximum dose we utilized), and regarded as not having activity. The genus Conyza(Asteraceae) is comprised of approximately 400 species and several species are known for their use in traditional medicine. ${ }^{39}$ Many ethnobotanical studies have documented the use of $C$. bonariensis in the ethnomedicines of different cultures. ${ }^{40-44}$ Previous studies have confirmed bioactive properties for specific Conyza species. ${ }^{45-51}$

C. bonariensis (leaves (MECbl) and root (MECbr) extracts) were selected based on its modest in vitro antibacterial activity results and the vast amount of studies done on different parts of the plants from different parts of the world.

In the popular medicines, different parts of $C$. bonariensis, in the form of infusion or decoction of its parts, are used as antiseptic, anti-ulcer- 
Table 4: Antibacterial activity in broth microdilution assay of selected medicinal plant methanolic extracts from the state of Mato Grosso, Brazil.

\begin{tabular}{|c|c|c|c|c|c|c|c|c|c|}
\hline \multirow[t]{2}{*}{ Plants } & \multicolumn{9}{|c|}{ Bacteria (MIC, $\mu \mathrm{g} / \mathrm{mL}$ ) } \\
\hline & Ef & $\mathrm{Sa}$ & $S p$ & $E a$ & $E C$ & $K p$ & $\mathrm{~Pa}$ & $P m$ & Sf \\
\hline MEAhl & 1000 & 1000 & 500 & 500 & 500 & 500 & 500 & 500 & 250 \\
\hline MEC $p$ & 1000 & 1000 & 500 & 500 & 500 & 500 & 250 & 500 & 1000 \\
\hline$M E G b$ & 250 & 1000 & 250 & 250 & 1000 & 500 & 500 & 1000 & 1000 \\
\hline $\mathrm{MECr}$ & 500 & 1000 & 500 & 1000 & 1000 & 1000 & 250 & 1000 & 1000 \\
\hline MELp & 1000 & 1000 & 250 & 1000 & 1000 & 1000 & 250 & 1000 & 1000 \\
\hline MESr & 500 & 1000 & 1000 & 125 & 500 & 500 & 500 & 500 & 500 \\
\hline $\mathrm{MeHh}$ & 250 & 500 & 1000 & 1000 & 1000 & 1000 & 1000 & 1000 & 500 \\
\hline $\mathrm{MECbl}$ & 250 & 1000 & 500 & 500 & 1000 & 1000 & 500 & 1000 & 1000 \\
\hline
\end{tabular}

Table 5: Antifungal activity of selected medicinal plant methanolic extracts from the state of Mato Grosso, Brazil, by agar disc diffusion method.

\begin{tabular}{|c|c|c|c|c|c|}
\hline \multirow[t]{3}{*}{ Extract } & \multicolumn{5}{|c|}{ Diameter of inhibition zone $(\mathrm{mm})$} \\
\hline & \multicolumn{5}{|c|}{ Leveduriform } \\
\hline & Candida kruzei & Candida parapsilosis & Candida glabrata & Candida albicans & Candida albicans \\
\hline MEAhl & -- & -- & -- & -- & -- \\
\hline MEAhs & -- & -- & -- & -- & -- \\
\hline-- & -- & -- & -- & -- & \\
\hline-- & -- & -- & -- & -- & \\
\hline MEC $P$ & -- & -- & -- & -- & -- \\
\hline $\mathrm{MEG} b$ & 10 & -- & -- & -- & -- \\
\hline 10 & -- & -- & -- & -- & \\
\hline 10 & 10 & 10 & -- & -- & \\
\hline $\mathrm{MEPm}$ & -- & 15 & -- & -- & -- \\
\hline-- & 15 & -- & -- & -- & \\
\hline $\mathrm{MECr}$ & -- & -- & -- & 13 & -- \\
\hline MEL $p$ & -- & 10 & -- & -- & 10 \\
\hline-- & 10 & -- & -- & 10 & \\
\hline-- & -- & -- & -- & 13 & \\
\hline MESr & -- & -- & -- & -- & -- \\
\hline-- & -- & -- & -- & -- & \\
\hline-- & -- & -- & -- & -- & \\
\hline $\mathrm{MEHh}$ & -- & -- & -- & -- & -- \\
\hline-- & -- & -- & -- & -- & \\
\hline-- & -- & -- & -- & -- & \\
\hline $\mathrm{MECbl}$ & 10 & 15 & -- & -- & -- \\
\hline 10 & 15 & -- & -- & -- & \\
\hline 15 & 14 & -- & 10 & -- & \\
\hline $\mathrm{MECbr}$ & 15 & 10 & -- & 10 & 10 \\
\hline-- & -- & -- & -- & -- & \\
\hline-- & -- & -- & -- & -- & \\
\hline Amphotericin B & 11 & 20 & 18 & 18 & 25 \\
\hline
\end{tabular}

-- no inhibition of fungal growth observed ; Antifungal activity: inhibition zone $\geq 10 \mathrm{~mm}{ }^{6}$ 
Table 6: Antifungal activity in broth microdilution assay of selected medicinal plants from the state of Mato Grosso, Brazil.

\begin{tabular}{|c|c|c|c|c|c|}
\hline \multirow[b]{2}{*}{ Extract } & \multicolumn{5}{|c|}{ Leveduriform (MIC, $\mu \mathrm{g} / \mathrm{mL}$ ) } \\
\hline & $\begin{array}{l}\text { Candida albicans } \\
\text { ATCC } 10231\end{array}$ & $\begin{array}{l}\text { Candida albicans } \\
\text { ATCC } 64550\end{array}$ & $\begin{array}{l}\text { Candida glabrata } \\
\text { ATCC } 90030\end{array}$ & $\begin{array}{l}\text { Candida kruzei } \\
\text { ATCC } 6258\end{array}$ & $\begin{array}{l}\text { Candida parapsilosis } \\
\text { ATCC } 40058\end{array}$ \\
\hline MEAhl & 500 & 500 & 500 & 500 & 500 \\
\hline $\mathrm{MEC} P$ & 500 & 500 & 500 & 1000 & 500 \\
\hline $\mathrm{MECr}$ & 250 & 1000 & 1000 & 1000 & 1000 \\
\hline MELp & 250 & 500 & 1000 & 250 & 250 \\
\hline $\mathrm{MES} r$ & 500 & 500 & 125 & 500 & 1000 \\
\hline $\mathrm{MEHh}$ & 125 & 1000 & 500 & 500 & 250 \\
\hline
\end{tabular}

MIC = Minimum Inhibitory Concentration. Good activity: $\leq 100 \mu \mathrm{g} / \mathrm{mL}$; Moderate activity: $>100<500,100-500 \mu \mathrm{g} / \mathrm{mL} ;$ Weak activity: $>500<1000 \mu \mathrm{g} / \mathrm{mL} ;$ Inactive: $\geq 1000 \mu \mathrm{g} / \mathrm{mL}$

Table 7: Acute effects of oral administration of methanolic extracts of Conyza bonariensis leaves and root on general behavior activities in mice.

\begin{tabular}{cccc}
\hline Plant extracts & Dose $(\mathrm{mg} / \mathrm{kg}$ p.o.) & Behavioral changes & Death \\
\hline \multirow{4}{*}{ MEC $b l$} & 500 & None & $0 / 3$ \\
& 1000 & None & $0 / 3$ \\
& 2000 & None & $0 / 3$ \\
& 5000 & None & $0 / 3$ \\
\multirow{3}{*}{ MECbr } & 500 & None & $0 / 3$ \\
& 1000 & None & $0 / 3$ \\
& 2000 & None & $0 / 3$ \\
& 5000 & None & $0 / 3$ \\
\hline
\end{tabular}

MECbl and MECbr: methanolic extract of Conyza bonariensis leaves and root, respectively.

ative and hepatoprotective, in addition to several other ethno medicinal uses. ${ }^{45-51}$ In fact, promising results were obtained with the methanolic extract of $C$. bonariensis from Pakistan, as it demonstrated to be active in DMBA-induced skin carcinogenesis in vivo studies. ${ }^{52}$

Reasonable comparisons with previous studies could not be made for many reasons. We have summarized these studies in Table 9, with short comments added for clarifications. These include among others, the use of different antimicrobial assay methods from those we employed in this work and/or sometimes the experimental conditions were poorly described. For example, Avancini and Wiest ${ }^{53}$ (only reported that $1 \mathrm{~g}$ of the extract was macerated in $10 \mathrm{~mL}$ of hydroethanolic solution of $C$. bonariensis without stating the concentration of ethanol used, nor the yield of the extract so as to ascertain the active concentration. Sometimes different parts of the plants are used and or its essential oils ${ }^{54}$ or different solvents in most cases. Moreover, in some occasions, the concentrations used are ten or more folds higher than the maximum concentration we employed (Table 9).

We encountered similar impediments, as in the case of the in vitro antibacterial studies of $C$. bonariensis, while trying to compare our results with previously reported in vitro antifungal studies. Most reports with previous studies. See Table 9 for more details on these issues.. ${ }^{55}$ In vivo
Table 8: In vivo antibacterial activity methanolic extracts of Conyza bonariensis leaves and root in the systemic infection models in mice by Staphylococcus aureus and Escherichia coli.

\begin{tabular}{cccc}
\hline Plant extracts & $\begin{array}{c}\text { Doses }(\mathrm{mg} / \mathrm{kg}, \\
\text { p.o.) }\end{array}$ & \multicolumn{2}{c}{ Survival (\%) } \\
\cline { 3 - 4 } & & \multicolumn{2}{c}{ Bacterial species } \\
\hline \multirow{2}{*}{ MECbl } & 10 & 100 & $E c$ \\
& 50 & 100 & 50 \\
& 100 & 100 & 50 \\
MECbr & 500 & 100 & 60 \\
& 10 & 85 & 30 \\
& 50 & 85 & 10 \\
& 100 & 43 & 00 \\
Meropenem & 500 & 29 & 00 \\
& 20 & 100 & 00 \\
& & & 100 \\
\hline
\end{tabular}

Sa: Staphylococcus aureus; Ec: Escherichia coli; MECbl and MECbr: methanolic extract of Conyza bonariensis leaves and root, respectively.

acute toxicity is usually performed on drug candidate for the purposes of: classification and labeling, to provide basic information on the mode of toxic action of a substance if any, to help in the choice of dose of a new compound, as well as to help in dose determination in animal studies. ${ }^{56}$ We therefore conducted the Hippocratic screening, to evaluate the potential toxic properties of the extracts. The acute toxicity test of the extracts administered orally demonstrated the high safety margin of $\mathrm{MECbr}$ and MECbl, suggesting lack of toxicity at the level of dose to be used in the in vivo studies. The no adverse effect level (NOAEL) in the oral acute toxicity study of MECbl and MECbr was calculated to be above $5000 \mathrm{mg} / \mathrm{kg}$ b.w. The human equivalent dose (HED) of $5000 \mathrm{mg} /$ $\mathrm{kg}$ in the rats using body surface area was $405.4 \mathrm{mg} / \mathrm{kg}$ b.w. ${ }^{57}$ Although, there are no reports of the toxicity studies of Conyza bonariensis in the literature, toxicity of some other species of Conyza have been studied. Biological and pharmacological studies have been carried out to confirm these ethnomedicinal claims. ${ }^{45-51}$ 


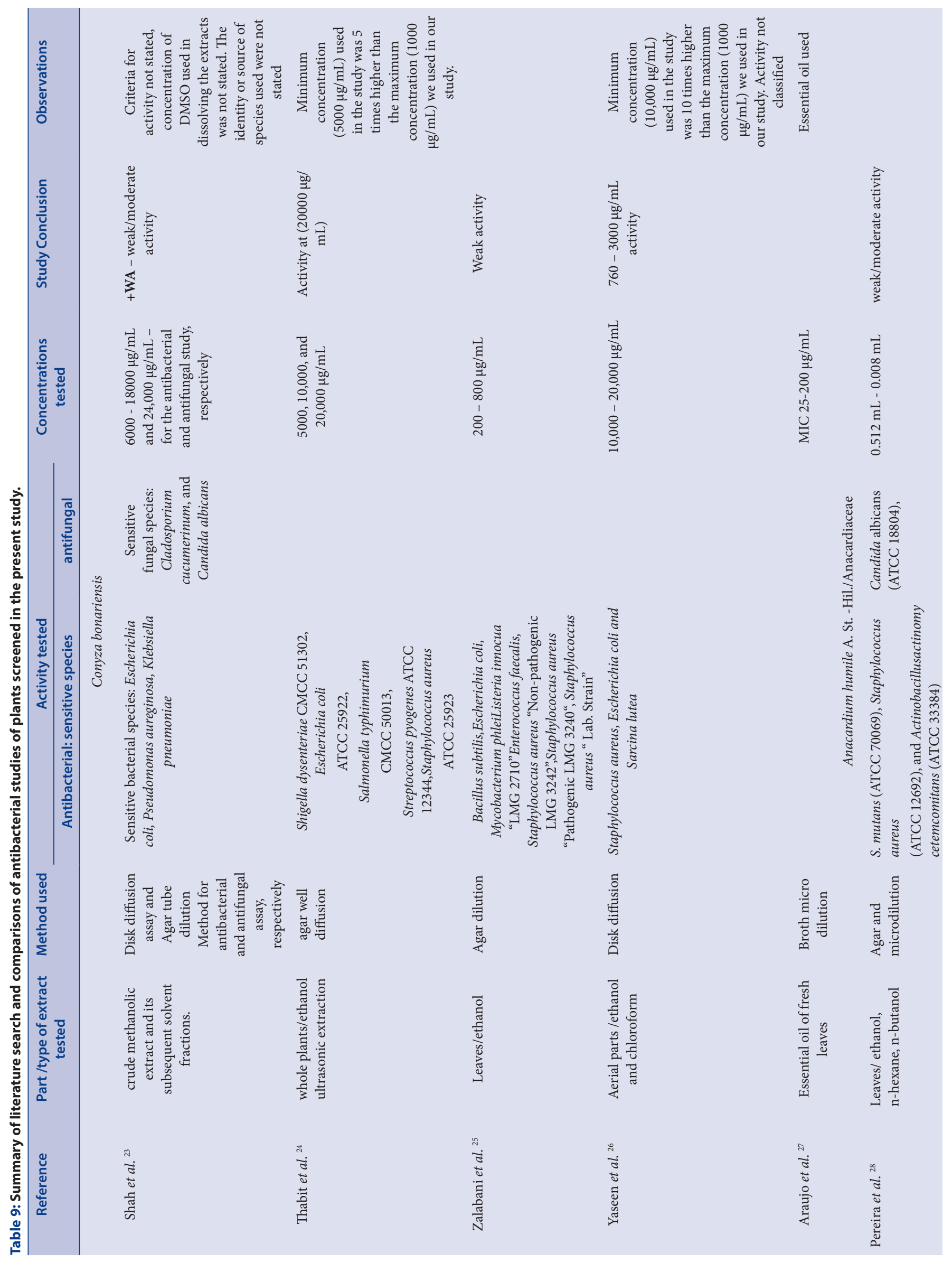




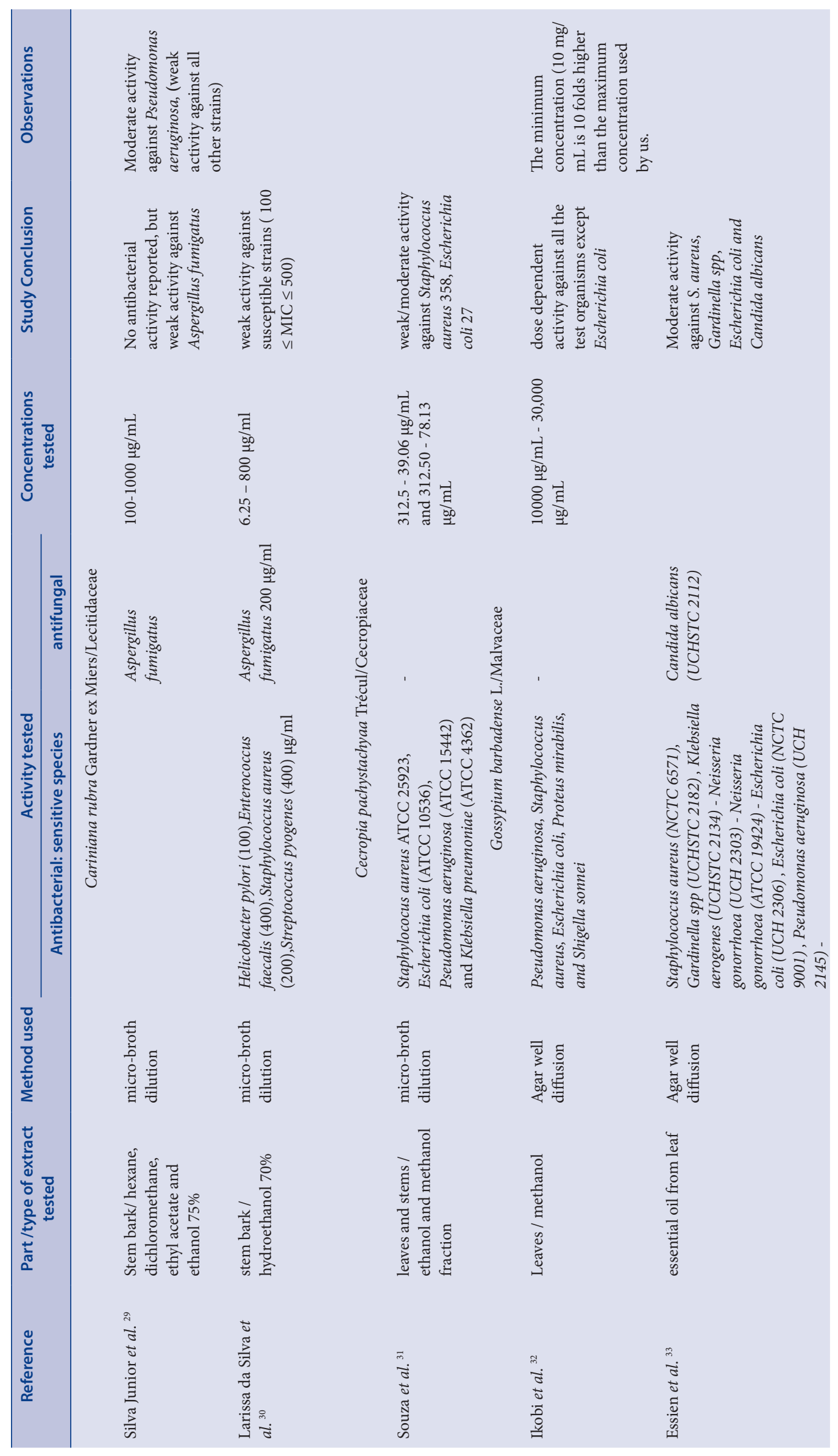




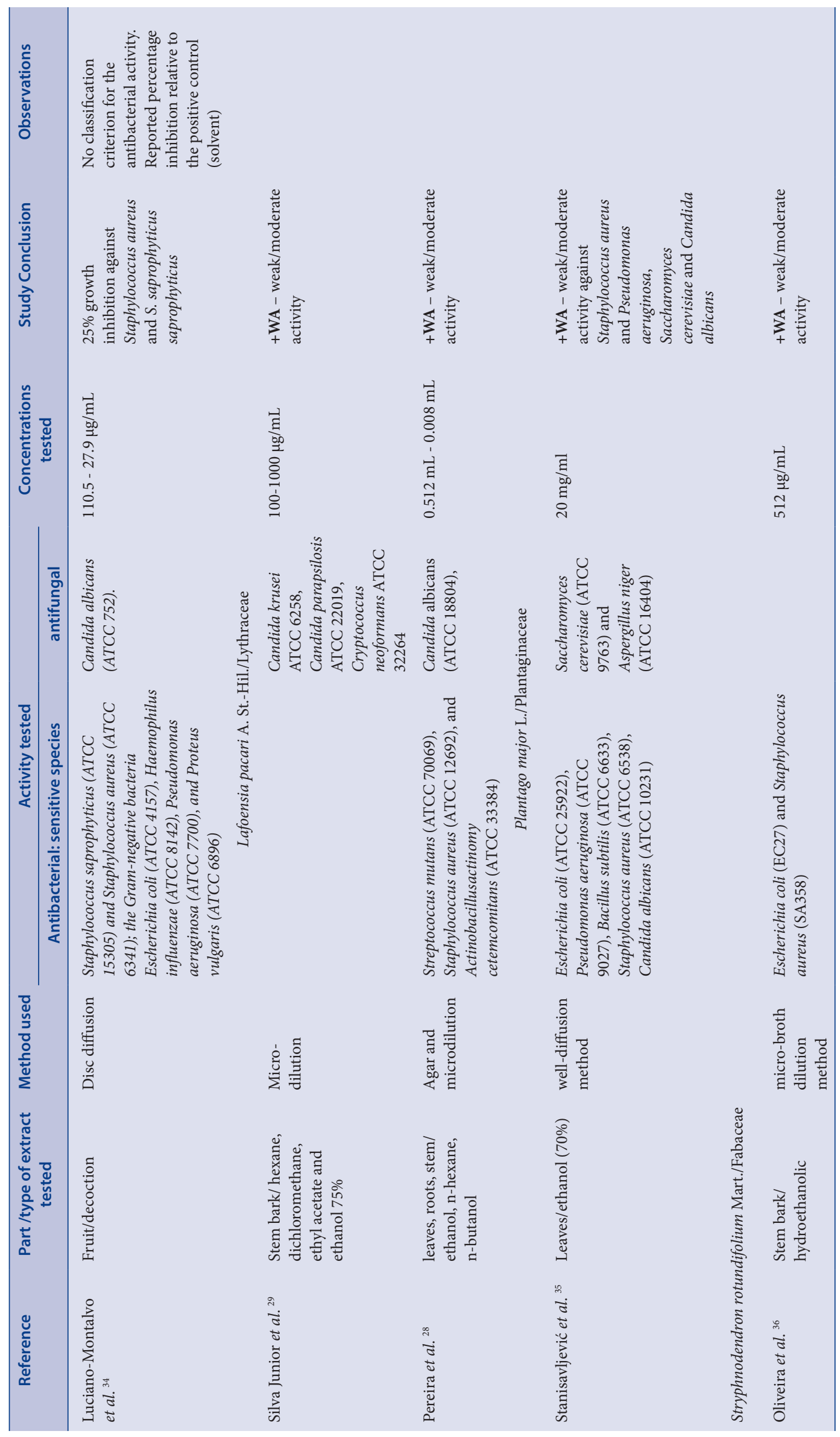


With these promising results of both the in vitro antimicrobial activities and the lack of in vivo acute toxicity, we proceeded to evaluate the in vivo antibacterial effects of the plant using S. aureus and E. coli systemic infection models.

However robust might be the results of in vitro studies, in vivo testing is without doubt one of the recognized, if not the most important, essential links between in vitro sensitivity testing and clinical studies in humans. Based on this fact, several regulatory agencies in many countries have made it as explicit requirements of experimental evaluation of new compounds in animals, destined for human, as part of guidelines for the clinical evaluation of efficacy and toxicity of anti-infective drugs, being prerequisites to clinical trials. ${ }^{58}$

Staphylococcus aureus is an important human pathogen responsible for many infectious diseases, sometimes life-threatening, including skin and soft tissue infections (SSTIs), foreign-body infections, bloodstream infections, just to mention but few, in both hospital and community settings. On the other hand, E.coli, is a known pathogen and one of the most frequent and lethal causes of bloodstream infections. ${ }^{59}$ We therefore selected these two bacterial strains for the in vivo antibacterial activity, based on their clinical relevance.

Our results from in vivo murine systemic infection model revealed that treatments with MECbl and MECbr demonstrated potential antibacterial activities, particularly, their prophylactic activity in the systemic infections caused by Gram-positive and Gram-negative microorganisms (S. aureus and E. coli).

The effect of MECbl was similar to that of the standard antibiotic, meropenem, in the case of $S$. aureus systemic infection, but milder in the case of $E$. coli. Thus, demonstrating the potential of this plant as an anti-bacterial agent. Considering the maximum dose $(500 \mathrm{mg} / \mathrm{kg})$ used in these studies, the HED is estimated at $40.5 \mathrm{mg} / \mathrm{kg}$. Simple comparison of this value with HED of the NOAEL shows that it is 10 folds less, further testifying to its high safety margin. In general, the in vivo antibacterial effect of MECbl and MECbr seem to be more effective on the Gram-positive bacterium (S. aureus) than the Gram-negative (E. coli) bacterium. The Gram-negative bacteria are implicated in the pathogenesis of severe sepsis and septic shock, although the exact mechanism is uncertain. A number of studies have been conducted to decipher the pathophysiological differences in bacteraemia with different causative bacterial species. In the study of patients admitted to the general intensive care unit (ICU) of a university teaching hospital by Abe et al. ${ }^{60}$ the authors observed that the incidence of Gram-negative bacteraemia was significantly higher in bacteraemia ICU patients with septic shock than in those with sepsis or severe sepsis. They concluded that the Gram-negative bacteraemia induces greater magnitude of inflammatory response than Gram-positive bacteraemia. In fact, these authors showed that the C-reactive protein and IL-6 levels were significantly higher in Gram-negative bacteraemia than in Gram-positive bacteraemia. These may actually explain the difference in the response to the extracts by these two bacterial strains, representing the Gram-negative and Gram-positive strains. ${ }^{61}$

We also observed that maximal positive response occurred at up to certain dose level, beyond which it declines (Table 8). The exact mechanism responsible for this effect is not known, but is sometimes seen in the effects of plants extracts and phytochemical compounds. ${ }^{62}$ However, the disc diffusion method is restrict to evaluate antimicrobial activities of plant extracts because the activity of the substances present in the extracts depends on the solubility of metabolites in the medium to act in the micro-organism. In the case of MESr the preliminary phytochemical analysis indicated the presence of various classes of secondary metabolites (free steroids, coumarins, reduced anthraquinones, saponins, tan- nins and flavonoids) many of non-polar categories. So it is probable that these substances have difficulty to diffuse across the agar, but if these are in direct contact with the bacterium like in the broth micro dilution method the solubility of the substances is not an impairment factor. ${ }^{63}$ Another possibility is that Enterobacter aerogenes is a Gram-negative bacterium and consequently is more resistant to antibiotic, because it has outer membrane that is not present in Gram-positive bacterium like Streptococcus pyogenes. The presence of saponins in the MESr may facilitate the penetration of the compounds across the outer membrane of bacterium. On the other hand, MEC $b 1$ presented in preliminary photochemical analysis only two classes of secondary metabolites (free steroids and coumarins). It is possible that the substances presents in MECbl have sufficient capacity to diffuse on the agar and exert their action againstStreptococcus pyogenes, a Gram-positive bacterium. It is noteworthy that we are talking about two different species of bacteria, one Gram-positive that is usually more sensitive to antibiotics and another Gram-positive in general, more resistant to antibiotics. ${ }^{64}$ Moreover, various hypotheses have been postulated to explain this phenomenon. These include the fact that many phytochemical compounds are pleitropic molecules that may act by binding to certain receptor. Desensitization of such receptor(s) may occur at higher drug dose, thereby resulting in little or no effect as compared to the lower dose. Increases in the dose may also triggered an untoward effect on other body systems, thereby provoking a negative response toward the antibacterial activity of observed. The induction or enzymatic systems (phase II), responsible for detoxification of xenobiotic. Taken together, it is probable that a higher dose predisposes the physiological system to excrete more of MECbl and MECbr, thus lowering their effective physiological concentration, and hence, diminished protective effects.

Preliminary phytochemical analysis of MECbl revealed the presence of flavonoids, coumarins and free steroids. There are considerable in formation in the literature detailing the antibacterial activities of the identified phytochemical constituents.

The antibacterial effects of MECbl and MECbr may therefore be due in part to the presence of the aforementioned metabolites, and possibly through a synergistic and or combined effects and may be responsible for its antibacterial activity established in this study. To the best of our knowledge, this is the first study dealing with the in vivo antibacterial activity of MECbl and MECbr.

\section{CONCLUSION}

In conclusion, systemic infection studies demonstrated that $C$. bonariensis had in vivo antimicrobial activity comparable to that of meropenem. This in vivo antimicrobial activity study confirmed that methanol extracts of $C$. bonariensis has high activity and deserves further investigation. The present results confirm previous in vitro studies by many researchers on different extracts of $C$. bonariensis further lending support to its use as anti-infective in traditional medicine. There is need for further studies to identify probable metabolites responsible for the in vivo antibacterial activity and possible mechanism of action of the extracts.

\section{ACKNOWLEDGEMENT}

We are very grateful to Fundação de Amparo à Pesquisa do Estado de Mato Grosso (FAPEMAT, Proc. no. 002.065/2008 and Proc. no. 205978/2011) and Coordenação de Aperfeiçoamento de Pessoal de Nível Superior (CAPES) for the award of postdoctoral fellowship to Dr. Karuppusamy Arunachalam (CAPES/PNPD, Proc. no. 23108.180072/201602). Instituto Nacional de Ciência e Tecnologia em Áreas Úmidas (INAU)/CNPq/MCTI (Proc. no. 704792/2009) for financial assistance. 


\section{CONFLICT OF INTEREST}

The authors declare that they have no conflicts of interests.

\section{ABBREVIATIONS}

ANOVA: Analysis of variance; ATCC: American Type Culture Collection; CEUA Committee on the Use of Animal for experimentation; LD: Lethal Dose 50; MEAhl and MEAhs: Methanolic extract of Anacardium humile leaves and stem bark; MECp: Methanolic extract of Cecropia pachystachya; MECbl and MECbr: Methanolic extract of Conyza bonariensis leaves and roots; MECr: Methanolic extract of Cariniana rubra; MEGb: Methanolic extract of Gossypium barbadense; MEHh: Methanolic extract of Handroanthus heptaphyllus; MELp: Methanolic extract of Lafoensia pacari; MEPm: Methanolic extract of Plantago major; MESr: Methanolic extract of Stryphnodendron rotundifolium; MIC: Minimal inhibitory concentration; sUFMT: Universidade Federal de Mato Grosso.

\section{REFERENCES}

1. Nolte $O$. Antimicrobial resistance in the $21^{\text {st }}$ century: A multifaceted challenge. Protein Pept Lett. 2014;21(4):330-5.

2. World Health Organization. The top 10 causes of death. Fact sheets. http:// www.who.int/news-room/fact-sheets/detail/the-top-10-causes-of-death. Published 2018. Accessed June 24, 2018.

3. Jim O'Neill. Review on Antimicrobial Resistance. Tackling a Global Health Crisis: Initial Steps. 2015. https://amr-review.org/sites/default/files/Report-52.15. pdf (Accessed on: 04.09.2017)

4. Harvey AL, Edrada-Ebel R, Quinn RJ. The re-emergence of natural products for drug discovery in the genomics era. Nat Rev Drug Discov. 2015;14(2):111-29.

5. Ribeiro RV, Bieski IG, Balogun SO, De Oliveira, Martins DT. Ethnobotanical study of medicinal plants used by Ribeirinhos in the North Araguaia microregion, Mato Grosso, Brazil. J Ethnopharmacol. 2017;1(1):1-8.

6. Silva IF, Filho VC, Zacchino SA, Lima JC, Martins DT. Antimicrobial screening of some medicinal plants from Mato Grosso Cerrado. Brazilian J Pharmacogn. 2009;19(1):242-8

7. Ríos JL, Recio MC. Medicinal plants and antimicrobial activity. J Ethnopharmacol. 2005;100(1-2):80-4.

8. Bieski IG, Leonti M, Arnason JT, Ferrier J, Rapinski M, Violante IM, et al. Ethnobotanical study of medicinal plants by population of Valley of Juruena Region, Legal Amazon, Mato Grosso, Brazil. J Ethnopharmacol. 2015:173;383-423. doi:10.1016/j.jep.2015.07.025

9. Kremer D, Košir IJ, Končić MZ, Čerenak A, Potočnik T, Srečec $S$, et al. Antimicrobial and Antioxidant Properties of Satureja montana L. and S. Subspicata Vis. (Lamiaceae). Curr Drug Targets. 2015;16(14):1623-33.

10. Pereira EM, Gomes RT, Freire NR, Aguiar EG, Brandão MD, Santos VR. In vitro antimicrobial activity of Brazilian medicinal plant extracts against pathogenic microorganisms of interest to dentistry. Planta Med. 2011;77(4):401-4.

11. Gangoue-Pieboji J, Eze N. The in-vitro antimicrobial activity of some medicinal plants against $\beta$-lactam-resistant bacteria. J Infect Dev Ctries. 2009;3(9):671-80

12. Shah NZ, Muhammad N, Azeem S, Khan AZ, Samie M, Khan H. Antimicrobial and phytotoxic properties of Conyza bonariensis. Pharm Pharmacol Res. 2013;1(1):8-11.

13. CIOMSMHO. International ethical guidelines for biomedical research involving human subjects. Bull Med Ethics. 2002;(182):17-23.

14. Samuelsen AB. The traditional uses, chemical constituents and biological activities of Plantago major L. A review. J Ethnopharmacol. 2000;71(1-2):1-21.

15. Bukhari IA, Shah AJ, Khan RA, Meo SA, Khan A, Gilani AH. Gut modulator effects of Conyza bonariensis explain its traditional use in constipation and diarrhea. Eur Rev Med Pharmacol Sci. 2013;17(4):552-8.

16. Matos FJA. Introdução à Fitoquímica Experimental 3, Third. Ed. UFC, Fortaleza. 2009 .

17. Kirby W, Bauer A, Sherris J, Turk M. Antibiotic susceptibility testing by standard single disk method. Am J Clin Pathol. 1966;45(4):493-6.

18. CLSI. Clinical and Laboratory Standards Institute, formely NCCLS (National Committee for Clinical Laboratory Standards). Methods for Diluition Antimicrobial Susceptibility Test for Bacteria That Grow Aerobically; Approved StandardNCCLS Document M7-A6, sixth ed. Pennsylvania, USA. 2003.

19. Rex JH, Alexander BD, Andes D, Arthington-Skaggs B, Brown SD, Chaturvedi $V$, et al. Reference method for broth dilution antifungal susceptibility testing of yeasts: approved standard - third edition. Clin Lab Stand Inst. 2008:1-25.

20. Holetz FB, Pessini GL, Sanches NR, Cortez DA, Nakamura CV, Dias Filho BP. Screening of some plants used in the Brazilian folk medicine for the treatment of infectious diseases. Mem Inst Oswaldo Cruz. 2002;97(7):1027-31.
21. Malone MH, Robichaud RC. A Hippocratic screen for pure or crude drug materials. Lloyd. 1962;25(4):320-32.

22. Meyer B, Ferrigni NR, Putnam JE, Jacobsen LB, Nichols DE, McLaughlin JL. Brine Shrimp?: A Convinient General Bioassay for Active Plant Consyituents. Kournal Med Plant Res. 1982;45(5):31-4

23. Shah NZ, Muhammad N, Azeem S, Khan AZ, Samie M, Khan H. Antimicrobial and phytotoxic properties of Conyza bonariensis. Pharm Pharmacol Res. 2013;1(1):8-11.

24. Thabit RAS, Cheng XR, Tang X, Sun J, Shi YH, Le GW. Antioxidant and antibacterial activities of extracts from Conyza bonariensis growing in Yemen. Pak J Pharm Sci. 2015;28(1):129-35.

25. Zalabani SM El, Hetta MH, Ismail AS. Genetic profiling, chemical characterization and biological evaluation of two conyza species growing in Egypt. J Appl Pharm Sci. 2012;2(11):54-61.

26. Yaseen M, Irshad N, Qayyum MI, Kamal Y. Evaluation of antibacterial and cholinomimetic activities of different extracts of Conyza bonariensis. Indian J Adv Plant Res. 2014;1(4):37-40.

27. Araujo L, Moujir LM, Rojas J, Rojas L, Carmona J, Rondon M. Chemical composition and biological activity of Conyza bonariensis essential oil collected in Mérida, Venezuela. Natural Product Communications. 2013:8(8):1175-8.

28. Pereira EM, Gomes RT, Freire NR, Aguiar EG, Brandão MDGL, Santos VR. In vitro antimicrobial activity of Brazilian medicinal plant extracts against pathogenic microorganisms of interest to dentistry. Planta Med. 2011;77(4):401-4.

29. Silva Junior IE, Cechinel Filho V, Zacchino SA, Lima JC, Martins DT. Antimicrobial screening of some medicinal plants from Mato Grosso Cerrado. Revista Brasileira de Farmacognosia. 2009:19(1B):242-8.

30. Larissa SI, Karuppusamy A, Fabio M, Ivana MPV, Isanete GCB, Sikiru OB, et al. Antimicrobial and antioxidant activities of selected plants used by populations from Juruena Valley, Legal Amazon, Brazil. Int J Pharm Pharm Sci. 2017;9(5).

31. Souza, Daniele O, Saulo RT, Fernando GF, Maria CMB, Maria FBMB, et al. "Antibacterial and modulatory activity of Cecropia pachystachya Trécul on the action of aminoglycosides."Revista Cubana de Plantas Medicinales.2014;19(3):121-32

32. Ikobi EU, Igwilo Cl, Awodele O, Azubuike PC. Antibacterial and wound healing properties of methanolic extract of dried fresh Gossypium barbadense leaves. Asian Journal of Biomedical and Pharmaceutical Sciences.2012;2(13):32.

33. Essien EE, Aboaba SO, Ogunw IA. Constituents and antimicrobial properties of the leaf essential oil of Gossypium barbadense (Linn.).Journal of Medicina Plants Research.2011;5(5):702-5.

34. Luciano-Montalvo C, Boulogne I, Gavillán-Suárez J. A screening for antimicrobial activities of Caribbean herbal remedies. BMC Complementary and Alternative Medicine.2013;13(1):126.

35. Stanisavljević IT, Stojičević SS, Veličković DT, Lazić ML, Veljković VB. Screening the antioxidant and antimicrobial properties of the extracts from plantain (Plantago major L.) leaves.Separation Science and Technology.2008;43(14):3652-62.

36. Oliveira DR, Brito-Junior FE, Bento EB, Matias EF, Sousa ACA, Costa JG, et al. Antibacterial and modulatory effect of Stryphnodendron rotundifolium. Pharmaceutical Biology. 2011;49(12):1265-70.

37. CLSI. Performance Standards for Antimicrobial Susceptibility Testing; Seventeenth Informational Supplement. 2007. doi:1-56238-525-5.

38. Barry A, García F, Thrupp L. An improved single-disk method for testing the antibiotic susceptibility of rapidly growing pathogens. Am J Clin Pathol. 1970;113(1):149-58

39. Martínez RMG, Richard-Greenblatt M, Juárez ZN, Av-GayY, Bach H, Hernández LR. Antimicrobial, Anti-Inflammatory, Antiparasitic, and Cytotoxic Activities of Laennecia confusa. Sci World J. 2012;1-8.

40. Bekalo TH, Woodmatas SD, Woldemariam ZA. An ethnobotanical study of medicinal plants used by local people in the lowlands of Konta Special Woreda southern nations, nationalities and peoples regional state, Ethiopia. J Ethnobio Ethnomed. 2009;5(1):26. doi:10.1186/1746-4269-5-26

41. Bieski IGC, Leonti M, Arnason JT, et al. Ethnobotanical study of medicinal plants by population of Valley of Juruena Region, Legal Amazon, Mato Grosso, Brazil. J Ethnopharmacol. 2015;173:383-423. doi:10.1016/j.jep.2015.07.025

42. Almeida CFCBR, Ramos MA, Silva RRV, et al. Intracultural variation in the knowledge of medicinal plants in an urban-rural community in the atlantic forest from northeastern Brazil. Evid Based Complement Alternat Med. 2012;679373. doi:10.1155/2012/679373

43. Liporacci HSN. Plantas medicinais e alimentícias na Mata Atlântica e Caatinga: uma revisão bibliográfica de cunho etnobotânico. 2015.

44. Duke JA. Duke's Handbook of Medicinal Plants of Latin America. (BogenschutzGodwin MJ, Ottesen AR, eds.). New York, NY: CRC Press, Taylor and Francis Group. 2009. doi:10.1201/9780849382031

45. Agra MF, Silva KN, Basílio IJLD, Freitas PF, Barbosa-Filho JM. Survey of medicinal plants used in the region Northeast of Brazil. Rev Bras Farmacogn. 2008;18(3):472-508. doi:10.1590/S0102-695X2008000300023

46. Zalabani SM El, Hetta MH, Ismail AS. Genetic profiling, chemical characterization and biological evaluation of two conyza species growing in Egypt. J Appl Pharm Sci. 2012;2(11):54-61. doi:10.7324/JAPS.2012.21110

47. Yaseen M, Irshad N, Qayyum MI, Kamal Y. Evaluation of antibacterial and cho- 
linomimetic activities of different extracts of Conyza bonariensis. Indian J Adv Plant Res. 2014;1(4):37-40

48. Calzada F, Cedillo-Rivera R, Mata R. Antiprotozoal activity of the constituents of Conyza filaginoides. J Nat Prod. 2001;64(5):671-3.

49. Chaudhry BA, Janbaz KH, Muhammad, Uzair ASE. Biological Studies of Conyza and Euphorbia species. J Res. 2001;12(1):85-88.

50. Harraz FM, Hammoda HM, Ghazouly MG, Farag MA, El-Aswad AF, Bassam SM. Chemical composition, antimicrobial and insecticidal activities of the essentia oils of Conyza linifolia and Chenopodium ambrosioides. In: Natural Product Research. 2015:29(9);879-82. doi:10.1080/14786419.2014.988714

51. Calzada F, Cedillo-Rivera R, Mata R. Antiprotozoal activity of the constituents of Conyza filaginoides. J Nat Prod. 2001;64(5):671-3.

52. Saleem M, Naseer F, Hussain K. Cytotoxic effect of methanol extract of on DMBA-induced skin carcinogenesis: An in vivo study. Bangladesh Journal of Pharmacology. 2015;10(2):467-74.

53. Avancini CAM, Wiest JM. Etnomedicina veterinária, etnonosotaxia e etnoter apêutica de doenças de pele como referência para seleção e avaliação preliminar da atividade antibacteriana de plantas nativas no sul do Brasil. Rev Bras Plantas Med. 2008;10(1):21-8.

54. Araujo L, Moujir LM, Rojas J, Rojas L, Carmona J, Rondón M. Chemical composition and biological activity of Conyza bonariensis essential oil collected in Mérida, Venezuela. Nat Prod Commun. 2013;8(8):1175-8.

55. Silva, Fernandes. Biological properties of medicinal plants?: A review of their antimicrobial activity. 2010;16(3):402-13.

56. Ukwuani AN, Abubakar MG, Hassan SW, Agaie BM. Toxicological Studies of
Hydromethanolic Leaves Extract of Grewia crenata. Int J Pharm Sci Drug Res. 2012;4(4):245-9

57. Reagan-Shaw $S$, Nihal M, Ahmad N. Dose translation from animal to human studies revisited. The FASEB journal. 2008;22(3):659-61.

58. Arunachalam K, Ascêncio SD, Soares IM, Souza ARW, Da Silva LI, De Oliveira RG, et al. Gallesia integrifolia (Spreng.) Harms: In vitro and in vivo antibacterial activities and mode of action. J Ethnopharmacol. 2016;184:128-37.

59. Wang S, Zhao SY, Xiao SZ, Gu FF, Liu QZ, Tang J, et al. Antimicrobial Resistance and Molecular Epidemiology of Escherichia coli Causing Bloodstream Infections in Three Hospitals in Shanghai, China. PLoS One. 2016;11(1):e0147740.

60. Abe R, Oda S, Sadahiro T, Nakamura M, Hirayama Y, Tateishi Y, et al. Gram-negative bacteremia induces greater magnitude of inflammatory response than Gram-positive bacteremia. Crit Care. 2010;14(2):R27.

61. Alexandraki I, Palacio C. Gram-negative versus Gram-positive bacteremia: what is more alarmin(g)?. Crit Care. 2010;14(3):161.

62. Beserra AM, Calegari PI, Souza MD, Dos Santos RA, Lima JC, Silva RM, et al. Gastroprotective and ulcer-healing mechanisms of ellagic acid in experimental rats. J Agric Food Chem. 2011;59(13):6957-65

63. De Bona E, da Silva Pinto FG, Fruet TK, Jorge TC, de Moura AC. Comparação de métodos para avaliação da atividade antimicrobiana e determinação da concentração inibitória mínima (cim) de extratos vegetais aquosos e etanólicos. Arquivos do Instituto Biológico. 2014:81(3):218-25

64. Vasconcelos JAA, Menezes EA, Cunha FA, Cunha MD, Braz BH, Capelo LG, Silva $\mathrm{CL}$, et al. Comparação entre microdiluição e disco difusão para o teste de susceptibilidade aos antifúngicos contra Candida spp. Semina Cienc. Biol. Saude. 2012;33(1):135-42.

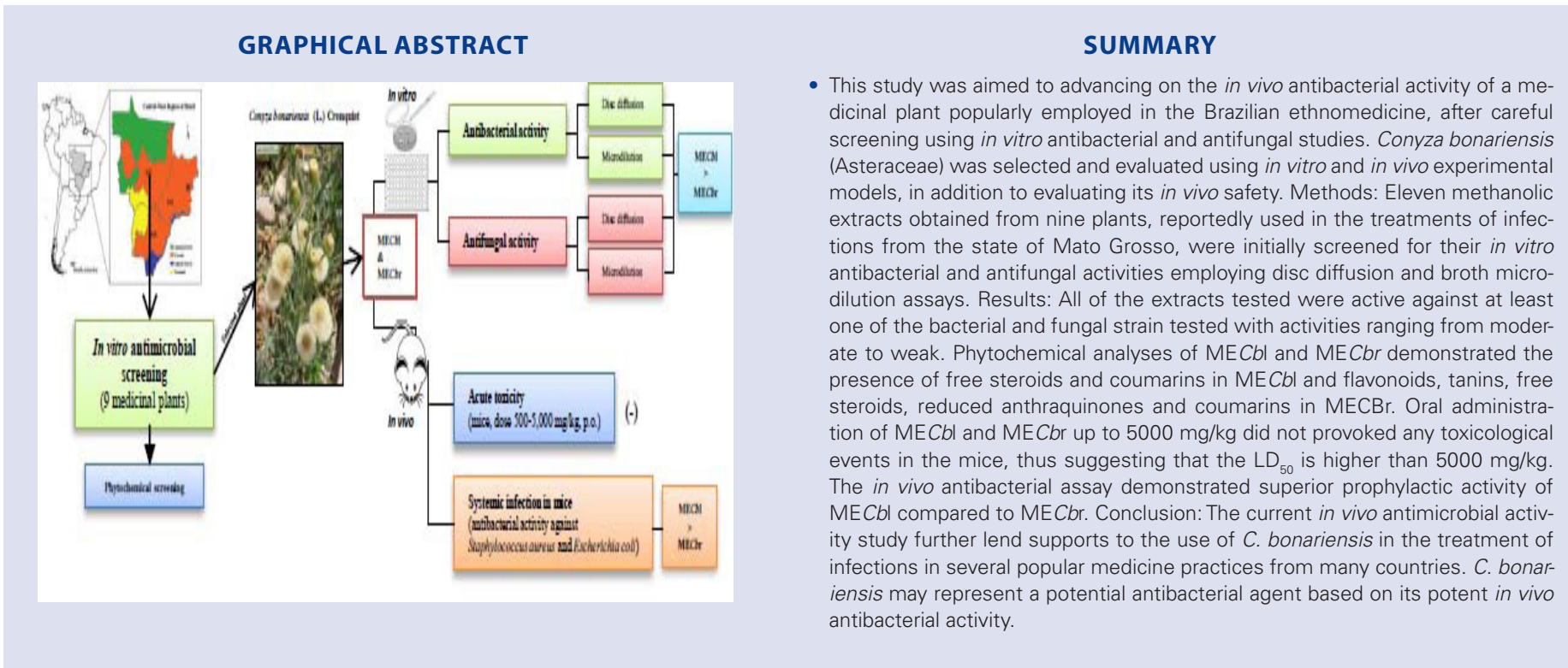

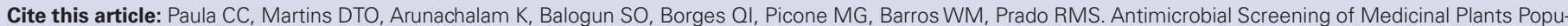

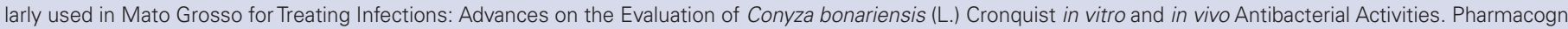
J. 2018;10(6)Suppl:s152-s166. 